\title{
ESSENTIAL ELEMENTS OF TAXATION - INVESTMENT PROTECTION AND DISPUTE SETTLEMENT
}

\section{Stefano Castagna*}

\section{A. INTRODUCTION}

B. TAX WITHIN INTERNATIONAL INVESTMENT PROTECTION

1. Protection of investment and taxation in international investment agreements

a. Jurisdiction of investment tribunals over tax matters and topical exclusions of jurisdiction

b. Consequences of the jurisdiction of international investment arbitral tribunals

2. The effect of tax liability on full compensation and damages valuation
18.01

18.03

18.03

18.18
C. INTERNATIONAL TAX DISPUTE SETTLEMENT 18.27

1. The OECD approach to dispute settlement in international tax law

2. International tax dispute settlement in the European Union

18.42

D. SOFT LAW STANDARDS IN TAXATION AND THEIR POTENTIAL PRACTICAL USES IN INVESTMENT ARBITRATION

E. CONCLUSION

\section{A. INTRODUCTION}

18.01 When matters of investment and international operations are intertwined with elements of taxation, thorny issues tend to present themselves at the practitioner's doorstep. Investment arbitration is sufficiently complex by itself, as are international tax arbitration cases. The reciprocal impact and potential interactions between international investment arbitration and international taxation is a topic where one must humbly ${ }^{1}$ acknowledge that there will never be a hard drive large enough to store all solutions to all issues that might arise. ${ }^{2}$ It might be difficult even for the best practitioner to anticipate how the tax liability in relation to the damages awarded to a claimant by an investment tribunal will be treated by the jurisdictions involved, or how a tax administration will address the taxation of a given operation between multiple related entities. One should therefore be particularly careful in managing risk. On the other hand, investment tribunals have struggled to juggle maintaining equilibrium between the rights of claimants and respondents in various instances, including tax audits and indirect

* Date of submission: 25/05/2020.

1 For a discussion on humility, knowledge and deficiency, see Thomas Aquinas, Summa Theologiae (New York: Benziger Brothers 1911-1925) IIa-IIae Q 161.

2 Just for the record, the OECD has specifically addressed possible overlaps in relation to international taxation and the international trade regime. See OECD, Model Tax Convention on Income and on Capital (OECD Publishing 2017), Commentary to art 25 paras $88-94$. 
expropriation cases. It is striking, however, that only in the recent past has academia begun to recognize the importance of knowing the main aspects of and interplay between taxation and investment arbitration. Relevant sums of money are at stake when taxation issues are argued in investment cases, and there is much that the dispute settlement regimes of both specialties of law may benefit from considering the best practices adopted by the other.

This chapter will focus first on providing an introduction to the most relevant issues that could arise in relation to tax and international investment, giving particular weight to investment protection standards. It will then turn to consider international tax dispute resolution, and thirdly how the particular characteristics of this latter regime may be helpful in the context of the international investment arena.

\section{B. TAX WITHIN INTERNATIONAL INVESTMENT PROTECTION}

\section{Protection of investment and taxation in international investment agreements}

\section{a. Jurisdiction of investment tribunals over tax matters and topical exclusions of jurisdiction}

In investment arbitration, host States are generally held accountable for measures taken against a foreign investor whose rights were guaranteed through a promise of the host government, either through local legislation, international treaty or contract. Any contested measure falling within the scope of an IIA, will likely be subject to the scrutiny of an international arbitral tribunal or court having jurisdiction over the matter, including tax measures, in the absence of a specific carve-out.

There is however no uniform definition of 'tax' nor 'tax measure' within the realm of international investment law. ${ }^{3}$ Some instruments provide for a limited definition. An example is given by the Energy Charter Treaty (ECT) at Article 21.7 for the very purpose of a tax carve-out, which states:

(a) The term 'Taxation Measure' includes: (i) any provision relating to taxes of the domestic law of the Contracting Party or of a political subdivision thereof or a local authority therein; and (ii) any provision relating to taxes of any convention for the avoidance of double taxation or of any other international agreement or arrangement by which the Contracting Party is bound. ${ }^{4}$

It is even harder to find a definition of what is 'tax'. This might be problematic in cases where one has to distinguish between what is 'tax', what is a 'fee' and other financial disbursements, such as special levies (often known as 'royalties'). ${ }^{5}$ To distinguish what is a tax from what is not a tax, one should look at the substance of the measure itself ${ }^{6}$ and not formal labels, especially considering the scope and the aim of the protections accorded to the investor by parties to the

3 Paul HM Simonis, 'BITs and Taxes' (2014) 42 Intertax 234, 240.

4 Energy Charter Treaty (adopted 17 December 1994, entered into force 16 April 1998) 2080 UNTS 95, art 21.

5 Thomas Wälde and Abba Kolo, 'Coverage of Taxation Under Modern Investment Treaties', in Peter Muchlinski, Federico Ortino and Christoph Schreuer (eds), The Oxford Handbook of Investment Law (OUP 2008) 317.

6 Ibid., 319. 
agreement. In addressing the matter, tribunals and courts have also resorted to the host State's definition of tax, even through the analysis of use of characterizations by local courts. ${ }^{7}$

18.06 A substantive analysis should be not only necessary when deciding whether a given measure is a tax measure and has impacted the operations of an investor in violation of its rights, ${ }^{8}$ but also when assessing whether a given tax-related item in a balance sheet can be deemed an investment. Per se tax advantages, credits and other rights should ordinarily not be considered 'investments' under an International Investment Agreement (IIA): these are not part of the operations of an investor, but impact on it only. Therefore, there should generally be no jurisdiction of an investment tribunal in case the issue relates to tax liabilities, credits or advantages per se, meaning deemed by themselves as a protected investment. This especially if one considers the objective and purpose of the agreement as part of the interpretative process of a treaty. ${ }^{9}$ IIAs aim at promoting investment which parties expect will (potentially) generate value, and they usually state in the agreement that such aims are the reasons for which the agreement has been signed. Obtaining or using tax benefits should not be sole or nearexclusive purpose of a protected investment. This notion might be relevant in peculiar, but possible circumstances. In the Republic of Italy, as in many other jurisdictions, there have been cases where the value of a company was essentially the tax-loss carryforward that it had (so-called 'tax coffins', or bare fiscali in Italian). This carryforward could not be used, because the company was constantly operating at loss and often had no expectation of improvement. Corporations generating a high amount of taxable revenue would merge with such a company to gain a tax advantage paying a portion of the tax loss carryforward to the owner of the 'coffin', being able to use the rest to abate their own taxable income. The tax regime has changed with the introduction of what is now Article 172.7 of Presidential Decree n. 917 of 1986 to avoid such use of M\&A operations.

18.07 Investments on essentially valueless companies, but for the possible connected tax benefits for which they could be used, should not be ordinarily considered falling within the notion of 'investment' unless there are other material reasons for the 'investment' to have taken place. In fact, as noted in the case of Value Added Tax (VAT) refunds, the OEPC tribunal found, amongst other VAT related decisions, that:

[i]t is not tenable to argue that there can be 'no doubt that under the Treaty the Refund Claim is an investment per se'. However broad the definition of investment might be under the Treaty it would be quite extraordinary for a company to invest in a refund claim. ${ }^{10}$

7 Antaris Solar GmbH and Dr Michael Göde v Czech Republic, PCA Case No 2014-01, Award, 2 May 2018, para 242. The tribunal has also found that while the contested measure was a tax under local law, it was not a tax under the ECT, since it had not the aim to collect revenue but reduce the level of Feed-in Tariffs that were payable to the investor (see para 253). Available at: <https://www.italaw.com/cases/2080> accessed 15 May 2020.

8 See as e.g., Occidental Exploration and Production Company (OEPC) v The Republic of Ecuador LCIA Case No UN3467, Final Award, 1 July 2004 (OEPC v Ecuador), paras 86-88, available at: <https://www.italaw.com/sites/default/files/ case-documents/ita0571.pdf> accessed 15 May 2020.

9 In this regard see, consider Tarcisio Gazzini, 'Objects(s) and Purpose(s)', in Tarcisio Gazzini (ed) Interpretation of International Investment Treaties (Hart Publishing 2016) 157.

10 OEPC v Ecuador (n 8), para 86. The tribunal found, however, that there had been other kinds of breaches in relation to the VAT refund scheme. 
One might say that this view was confirmed by the EnCana tribunal, which too ruled over whether Ecuadorian VAT refunds fell within the scope of the relevant Bilateral Investment Treaty (BIT), when it stated that 'the corresponding right to be paid is capable of falling within the broad scope of "amounts yielded by an investment". ${ }^{11}$ Therefore, the general key element to consider with regard to questions that are clearly pertaining to tax-related rights only, is whether the tax-related issues have a direct link to the operations of the protected investment and impact its (expected) cash flows owed to the investor. This of course unless the IIA, the applicable law and/or other applicable agreement state, or can be interpreted to mean, otherwise.

As noted above, States may exclude taxation issues from the scope of the protection of IIAs or the jurisdiction of any tribunal. States may also decide to expressly bind themselves to given tax-related commitments, such as the stabilization of their tax regime vis-à-vis an international investor. Therefore, the definition of 'tax' will be relevant only if an exception applies.

There may be several types of exclusions of tax matters within an IIA. There may be general exclusions, such as that present in the Cambodia-Singapore BIT'12 (" $\mathrm{t}]$ he provisions of this Agreement shall not apply to matters of taxation in the territory of either Contracting Party. Such matters shall be governed by any Avoidance of Double Taxation Treaty between the two Contracting Parties and the domestic laws of each Contracting Party'), specifications as to what treaty will prevail (e.g., India-Iceland BIT, ${ }^{13}$ which reads '[n]othing in this Agreement shall affect the rights and obligations of either Contracting Party derived from any tax convention. In the event of any inconsistency between the provisions of this Agreement and any tax convention, the provisions of the latter shall prevail'), specific exclusions based on the type of tax or protection (e.g., Canada-Tanzania BIT, ${ }^{14}$ which reads at Article 14.4 'the provisions of Articles 4 (National Treatment) and 5 (Most Favoured Nation Treatment) shall apply to all taxation measures, other than taxation measures on income, capital gains or on the taxable capital of corporations'), and the combination of exceptions within exclusions.

An additional limitation often found is a tax veto, also referred to as 'joined tax consultation'. ${ }^{15}$ This is typically not present to limit the substantive rights of an investor, but to impede or limit the investor's ability to file a claim through investment arbitration. An example of such provision can be found in the Japan-Peru BIT of 2008 at Article 23.5(b): ${ }^{16}$

11 EnCana Corporation v Republic of Ecuador LCIA Case No UN3481, Award 3 February 2006, paras 180-183, available at: <https://www.italaw.com/sites/default/files/case-documents/ita0285_0.pdf> accessed 15 May 2020.

12 Agreement between the Government of the Kingdom of Cambodia and the Government of the Republic of Singapore on the Promotion and Protection of Investments (adopted 4 November 1996, entered into force 24 February 2000), art 5.2 .

13 Agreement between the Government of the Republic of India and the Government of the Republic of Iceland for the Promotion and Protection of Investments (adopted 29 June 2007, entered into force 16 December 2008), art 4.4.

14 Agreement between the Government of Canada and the Government of the United Republic of Tanzania for the Promotion and Reciprocal Protection of Investments (adopted 17 May 2013, entered into force 9 December 2013), art 14.4.

15 Stefano Castagna, 'ICSID Arbitration: BITs, Buts and Taxation: An Introductory Guide' (2016) 7 Bulletin for Internal Taxation 375.

16 Agreement Between Japan and the Republic of Peru for The Promotion, Protection and Liberalisation of Investment (adopted 21 November 2008, entered into force 10 December 2009), available at: <https://investmentpolicy.unctad.org/ international-investment-agreements/treaty-files/1733/download> accessed 15 May 2020. 
[t]he investor shall refer the issue, at the time that it delivers the notice of intent under Article 18, to the competent authorities of both Contracting Parties to determine whether such [tax] measure is not an expropriation. If the competent authorities of both Contracting Parties do not consider the issue or, having considered it, fail to determine, within a period of 180 days of such referral, that the measure is not an expropriation, the investor may submit its claim to arbitration under Article 18. (c) For the purposes of subparagraph (b), the term "competent authorities" means: (i) with respect to Japan, the Minister of Finance or his or her authorised representatives, who shall consider the issue in consultation with the Minister for Foreign Affairs or his or her authorised representatives; and (ii) with respect to the Republic of Peru, the Minister of Economy and Finance (el Ministro de Economía y Finanzas), or his or her authorised representatives.

18.11 Finally, it should be noted that often IIAs guarantee the right to transfer capital, profits, interests and other type of financial flows to ensure the effectiveness of the rights of the investor. Such right, however, is at times expressly subject to the previous satisfaction of all tax liabilities to be borne by the investor itself. ${ }^{17}$

18.12 When no exception applies, other sources of law which relate to tax - other than the BIT may also be applicable to interpret the standards of investment protection under the IIA. This means that even tax treaties will be considered part of the law applicable to the investment. ${ }^{18}$ In such cases, tax disputes of foreign investors may be decided not only within the dispute resolution tools proper of Double Tax Treaties (DTTs), but through those of IIAs. It might also be possible, even with the presence of fork in the road provisions, ${ }^{19}$ that the investor/ taxpayer may have the possibility to try and obtain relief through the use of both regimes, since it is likely that there will not be any specific exclusion addressing the reciprocal use of the two tools, and surely dispute resolution tools under DTTs are not domestic remedies.

\section{b. Consequences of the jurisdiction of international investment arbitral tribunals}

18.13 Often, State 'measures' from which investors are protected in BITs and other IIAs include procedures and practices of the contracting parties. ${ }^{20}$ Tax imposition alone may be considered

17 As an e.g., see the Agreement between the Government of the Republic of Azerbaijan and the Government of the Syrian Arab Republic on the Promotion and Reciprocal Protection of Investments (adopted 8 July 2009, entered into force 4 January 2010), art 8.3(a).

18 Arno E Gildemeister, 'Chapter 12: Germany', in Michael Lang et al (eds) The Impact of Bilateral Investment Treaties on Taxation (IBFD 2017) 309.

19 These clauses provide that if the investor chooses to settle its claims through local court proceedings, the choice is final. See Christoph Schreuer, 'Travelling the BIT Route: Of waiting periods, Umbrella Clauses and Forks in the Road' (2004) 5 Journal of World Investment and Trade 240. One should note that fork in the road provisions may vary widely in terms of language, and therefore a thorough case-by-case analysis should be considered.

20 See, e.g., Agreement between Canada and the Slovak Republic on the Promotion and Protection of Investments (adopted 20 July 2010, entered into force 14 March 2012) art I (f); The Comprehensive Economic and Trade Agreement between the EU and Canada (CETA) [2017] OJ L11/23, art 1.1 'measure', available at: <http:// trade.ec.europa.eu/doclib/docs/2014/september/tradoc_152806.pdf> accessed 15 May 2020; Agreement for the Promotion and Protection of Investment between the Republic of Austria and the Federal Republic of Nigeria (adopted 8 April 2013), art 1 (f)7, available at: <https://investmentpolicy.unctad.org/international-investment-agreements/ treaty-files/2972/download> accessed 15 May 2020. 
tantamount to expropriation, with the condition that there is proof that 'as a direct consequence of the measures complained of [,] Claimant was deprived of its investment'. ${ }^{21}$ In addition, issues can arise when the government or parliament takes action in passing a bill or law, or in relation to the behaviour of the tax authorities or tax tribunals. ${ }^{22}$ This was the case of Mr Tza Yap Shum against Peru. In this particular case, the local tax authority, named Superintendencia Nacional de Aduanas y de Administración Tributaria (SUNAT) found irregularities during a tax audit, and as a consequence had de facto caused the interruption of the operations of the business of Mr Sum. The tribunal found that jointly to the violations of the investors' rights by the SUNAT, the tax tribunal called to decide on the appeal against the measures of the tax authority had failed to perform a substantive review of the SUNAT's actions and had not provided a truly reasoned decision on the matter. Consequently, there had also been a violation of the right of access to courts granted under the relevant BIT. ${ }^{23}$ There have also been instances in which a breach of National Treatment standards occurred due to tax imposition, such as the presence of excise taxes that could not be rebated - a possibility instead granted to national comparable operators. ${ }^{24}$ Tribunals have also found that Fair and Equitable Treatment (FET) clauses in BITs can be breached through the imposition of tax measures or the denial of certain tax benefits, such as in the case of withdrawal of a VAT certificate. $^{25}$

Practices in tax assessment and tax valuation may put a contracting party in the position of having violated the rights of an investor. This especially if there is a deviation from binding standards that have been codified and are routine in procedures such as tax audits. In addition, institutions such as the EU Joint Transfer Pricing Forum, which assists and advises the European Commission on transfer pricing matters, regularly issue documents on standards of treatment of assessment in international and domestic taxation, promoting best practices which are per se non-binding, however. ${ }^{26}$

Another institution that has drafted soft law guidelines is the Organisation for Economic Cooperation and Development (OECD). For example, in its latest version of the Transfer

21 Denying the presence of indirect expropriation measures, Link-Trading Joint Stack Company v Department for Customs Control of the Republic of Moldova, UNCITRAL, Final Award, 18 April 2002, para 91, available at: <https:// www.italaw.com/sites/default/files/case-documents/ita0468_0.pdf> accessed 15 May 2020.

22 See CMS Gas Transmission Company v The Republic of Argentina ICSID Case No ARB/01/8, Decision of the Tribunal on Objections to Jurisdiction, 17 July 2003, para 108:

In so far as the international liability of Argentina under the Treaty is concerned, it also does not matter whether some actions were taken by the judiciary and others by an administrative agency, the executive or the legislative branch of the State. Article 4 of the Articles on State Responsibility adopted by the International Law Commission is abundantly clear on this point. Unless a specific reservation is made in accordance with Articles 19, 20 and 23 of the Vienna Convention on the Law of Treaties, the responsibility of the State can be engaged and the fact that some actions were taken by the judiciary and others by other state institutions does not necessarily make them separate disputes. No such reservation took place in connection with the BIT.

Available at: <https://www.italaw.com/cases/288> accessed 15 May 2020.

23 Mr Tza Yap Shum v Republic of Peru ICSID Case No ARB/07/6, Award (Spanish), 7 July 2011, para 238.

24 See Marvin Feldman v Mexico ICSID Case No ARB (AF)/99/1, Award (English), 16 December 2002, para 173.

25 This was one of the elements through which the tribunal found a breach FET clause in Biwater Gauff (Tanzania) Ltd v United Republic of Tanzania, ICSID Case No ARB/05/22, Award, 24 July 2008, para 814; for denial of tax benefits, see $O E P C$ v Ecuador (n 8).

26 EU, 'EU Joint Transfer Pricing Forum: Report on the Use of Comparables in the EU' (JTPF/007/2016/FINAL/EN, 2016) 3. 
Pricing Guidelines (TPG), the OECD highlights that even when cooperation of the taxpayer during an audit is necessary, in any event the tax administration should not 'seek to impose such a high level of cooperation that would make it too difficult for reasonable taxpayers to comply'. ${ }^{27}$ If it is up to the taxpayer to prove that there has been tax compliance, tax administrations can raise assessments only when these are soundly grounded in law. ${ }^{28}$ The OECD further notes that good faith principles should guide both tax administrations and taxpayers in assessing tax issues during audits. ${ }^{29}$

18.16 Similar, but more detailed standards have been codified in non-binding instruments by the European Commission itself, such as the Guidelines for a Model for a European Taxpayers' Code, which are considered an aspiration to follow and provide 'a core of principles, which compiles the main existing rights and obligations that govern the relationships between taxpayers and tax administrations' and are an instrument that 'expects to provide European citizens with a convenient source of knowledge on the main rights and obligations they can expect when dealing with a tax administration in a Member State other than their State of residence'. ${ }^{30}$ The guidelines include, inter alia, model standards of conduct for audits and court and tribunal review. Although not part of a treaty or binding instrument, these principles might be of interest to an international tribunal for comparison between the actual treatment of an investor-taxpayer and what treatment should be expected by international standards for the purpose of ascertaining violation of rights such as FET standards. ${ }^{31}$

18.17 In addition, it should be noted that concepts related to FET and issues that are connected to investor expectations may arise from the complex structure of the multi-layered relationship of Member States of the European Union and the Union itself. This is the case of a recent State aid decision of the General Court of the European Union following the submission by the investor affected by the European Commission decision on the Fiat Finance and Trade (FFT) case, where the company now known as Fiat Chrysler Finance Europe, member of the FIAT Group, had reached an Advanced Pricing Arrangement (or 'APA', which will be addressed in section C.1) with Luxembourg. ${ }^{32}$ The agreement ascertained the taxable base for some operations of the group, but was found in violation of EU law by the Commission. The Commission's decision, according to the Court, did not violate the party's

27 OECD, OECD Transfer Pricing Guidelines for Multinational Enterprises and Tax Administrations (OECD Publishing 2017), chapter IV section B2 paras 4.11-14.

28 Ibid.

29 Ibid.

30 Commission, 'Guidelines for a Model for A European Taxpayers Code' Ref Ares (2016) 6598744, available at: $<$ https://ec.europa.eu/taxation_customs/business/tax-cooperation-control/guidelines-model-european-taxpayers-code_ en> accessed 15 May 2020.

31 As soft law practices and documents, at least under the definition of Marc Jacob and Stephan Schill. For a discussion on the role of such type of uses see José Enrique Alvarez, 'Reviewing the Use of "Soft Law" in Investment Arbitration' (NYU School of Law, Public Law Research Paper No 18-46, 2018), available at: <https://ssrn.com/abstract=3258737> accessed 15 May 2020.

32 See State aid SA.38375 (2014/C ex 2014/NN) which Luxembourg granted to Fiat (notified under document C (2015) 7152) Commission Decision 2016/2326 [2015] OJ L351/1, available at: <http://ec.europa.eu/competition/state_aid/ cases/253203/253203_1757564_318_2.pdf> accessed 15 May 2020; the judgment of the General Court (Seventh Chamber, Extended Composition) in Cases T-755/15 and T-759/15 Grand Duchy of Luxembourg and Fiat Chrysler Finance Europe v Commission [2019] ECLI:EU:T:2019:670, available at <http://curia.europa.eu/juris/document/ document.jsf?text=\&docid=218102\&pageIndex=0\&doclang=EN\&mode=1st\&dir $=\&$ occ $=$ first\&part $=1 \& c i d=362281>$ accessed 9 May 2020. 
rights. In its suit, claimant argued, amongst other things, that its legitimate expectations had been violated by the European Commission, since the APA had been agreed upon under the best practices of the OECD which had been allegedly adhered to by the Commission until then ('the contested decision breaches the principle of legitimate expectations since the Commission has created a legitimate expectation that for State aid purposes it assesses transfer pricing arrangements on the basis of the OECD Guidelines and its sudden departure from this has breached the principle of legitimate expectations' ${ }^{33}$ ). This obviously does not mean that a 'legitimate expectation' standard under EU State aid ${ }^{34}$ when applied in the context of tax law is equivalent to that of international investment law, but it must be noted that there can be significant amount of interplay between the various specialities, as noted in the introduction.

\section{The effect of tax liability on full compensation and damages valuation}

Taxation is not just a matter of substantive rights in investment arbitration. It also impacts on the worth of the damages provision of an award. This is particularly relevant since investment arbitration is used as a means to make up for a financial loss. If a claimant is to be successful in obtaining an award on damages, the tribunal will have typically ruled on the an (whether damages are due) and the quantum (amount) due. However, taxes will typically be owed on the damages awarded, and if full compensation must be accorded to the investor, such tax liability must be considered when rendering an award. ${ }^{35}$ This with the view that the claimant will be compensated for any additional tax that it will have to pay due to the award, versus what it would have paid had the violation not occurred.

The quantification of such additional tax liability may be complex to calculate, as taxation typically is connected to a given local territorial reality ${ }^{36}$ and the type of investment structure might have changed over time and be quite articulated, ${ }^{37}$ which might entail issues of double-taxation, often governed by DTTs. Article 13 of the Model Tax Convention regulates

33 Case T-759/15 Fiat Chrysler Finance Europe v Commission [2015] OJ C 59/49, available at: <https://eur-lex.europa.eu/ legal-content/EN/TXT/PDF/?uri=CELEX:62015TN0759\&from=EN> accessed 15 May 2020.

34 See for a brief analysis Commission (EU), 'Notice from the Commission - Towards an effective implementation of Commission decisions ordering Member States to recover unlawful and incompatible State aid' [2007] OJ C272/4, para 17, available at: <https://eur-lex.europa.eu/legal-content/EN/TXT/PDF/?uri=CELEX:52007XC1115(01)\&from= EN> accessed 15 May 2020.

35 Eddie Tobis, 'Avoiding Double Taxation on International Arbitration Awards' (2017) 4 Journal of Damages in International Arbitration 16.

36 Edoardo Traversa and Alice Pirlot, 'Chapter 6: Tax Sovereignty and Territoriality under Siege: How Far Should the EU Freedoms of Movement Impact on the Territorial Allocation of Taxing Powers between Member States?' in Cécile Brokelind (ed) Principles of Law: Function, Status and Impact in EU Tax Law (IBFD 2014) 125.

37 Tobis (n 35) 18. 
the right to tax capital gains, including those deriving from expropriation. ${ }^{38}$ However, arbitral tribunals appear to neglect an analysis of the role of possibly applicable DTTs. ${ }^{39}$

18.20 The issue pertains not just as to which jurisdiction will have the right to tax (or claims to have such right), but also as to which entity will ultimately bear the tax liability on the damages awarded. An additional matter to consider in quantifying the amount of damages suffered might be whether there has been a mitigation of losses from a tax perspective within the overall multinational group to which a claimant might belong. As an example, some jurisdictions enable the deduction of the losses incurred by subsidiaries from the calculation of taxable profits of the mother company. ${ }^{40}$

18.21 Another additional issue that could be relevant is how the jurisdiction having the right to tax the amount awarded will treat the damages granted: whether as income, capital gain or other category, ${ }^{41}$ or whether the investor will have the right to a rollover, and thus subject to tax liability further in the future. ${ }^{42}$

18.22 Consequently, tax liability must always be assessed, if necessary, on a case-by-case basis, with particular prudence as to the use to adequate counsel and expert opinion in understanding the interplay between the structure of the investment and the liability arising upon claimants. ${ }^{43}$ There is no general rule to answer what amount of tax will be due and by whom. It is necessary to understand how the consideration of the potential tax treatment will affect the net amount of compensation of final award rendered by the tribunal on a case-by-case basis. This safeguards both the host state and the claimant's rights. One should also note that tribunals have at times not accepted the idea that one should take into consideration the impact of tax

38 OECD Model Tax Convention (n 2), Commentary to Article 13, para 5 reads:

[t]he Article does not give a detailed definition of capital gains. This is not necessary for the reasons mentioned above. The words 'alienation of property' are used to cover in particular capital gains resulting from the sale or exchange of property and also from a partial alienation, the expropriation, the transfer to a company in exchange for stock, the sale of a right, the gift and even the passing of property on death.

39 Consider the position of claimant in the annulled award Occidental Petroleum Corporation Occidental Exploration and Production Company $v$ The Republic of Ecuador, ICSID Case No ARB/06/11, Award, 5 October 2012, paras 850-853 (Occidental v Ecuador), available at: <https://www.italaw.com/sites/default/files/case-documents/italaw1094.pdf> accessed 15 May 2020; Mobil Investments Canada Inc \& Murphy Oil Corp v Government of Canada, ICSID Case No $\mathrm{ARB}(\mathrm{AF}) / 07 / 4$, Decision on Liability and on Principles of Quantum (redacted), 22 May 2012, available at: <https://www.italaw.com/sites/default/files/case-documents/italaw1145.pdf> accessed 15 May 2019.

40 Consider a related issue from a tax perspective addressed in Case C-446/03 Marks \& Spencer plc v David Halsey (Her Majesty's Inspector of Taxes) [2005] ECLI:EU:C:2005:763 available at <http://curia.europa.eu/juris/showPdf.jsf?text= \&docid=57067\&pageIndex=0\&doclang=en\&mode=1st\&dir=\&occ=first\&part=1\&cid=15639586> accessed 25 May 2020. See also for a discussion of the Marks \& Spencer case, Michael Lang, 'Has the Case Law of the ECJ on Final Losses Reached the End of the Line?' in Madalina Cotrut (ed) ECJ direct tax compass 2014 (IBFD tax travel companions 2014) 530 .

41 Adam Scherer and Shane Rayman, 'Tax Implications of Expropriation' (2008) 56 Canadian Tax Journal/ Revenue Fiscale Canadienne 870, 883.

42 As in the case of South Africa. See South African Revenue Service, Guide to Capital Gains Tax (2000), 13. Available at: <http://www.treasury.gov.za/documents/national\%20budget/2000/cgt/cgt.pdf> accessed 15 May 2020; South African Revenue Service, Exclusions and Roll-Overs <https:/www.sars.gov.za/TaxTypes/CGT/Exclusions/Pages/default. aspx> accessed 25 May 2020.

43 As done in PSEG Global, Inc, The North American Coal Corporation, and Konya Ingin Electrik Üretim ve Ticaret Ltd Sirketi $v$ Republic of Turkey, ICSID Case No ARB/02/5, Award, 19 January 2007, paras 338-339. 
liability on an award of damages, and have also requested a detailed explanation of the justification of the reason as to why and how a tax liability should arise. ${ }^{44}$

In addressing the potential impact of tax liability on the amount awarded, tribunals have used two different approaches in dealing with the issue: calculating the damages owed on the basis of the pre-tax counterfactual cash flows of the investment, or taking into consideration a gross-up after calculating the liability due on an after-tax basis. In addition, the tribunal may resort to a further complementing option, which does not constitute a method of calculation of damages to be awarded, but consists in ensuring through the power of the tribunal that local tax liability owed to respondent will be fully satisfied by the respondent itself 45 or ask respondent to agree to ensure in the payment of a certain precise amount as tax liability (or grant no tax liability). While the best applicable approach may vary from case to case, the only constraint upon the arbitral tribunal seems to be to make a coherent decision as to the data and values judged appropriate in assessing what is due by respondent. ${ }^{46}$

In the first case, there must be an equivalence, on paper or as hypothesis, between the amount of tax that would have been owed if the investor had not suffered the loss (a counterfactual situation) and the tax liability arisen from the amount awarded. ${ }^{47}$ This, however, means that there must be a clear understanding of how the award of damages will be considered by the tax administration(s) involved, in order to ensure the rights of claimant to full compensation. As mentioned above, this may by no means be an easy task, especially taking into consideration that the damages awarded may be considered to have a different taxable nature than the counterfactual cash flows, and therefore be taxed differently.

The second possible way of taking into account tax liability consists in calculating damages on an after-tax basis with a gross-up to account for payable tax. This seems to be easier when considering issues of both valuation and legal analysis. ${ }^{48}$ However, there are still issues with the application of this methodology, since there must be a relative certainty as to the burden of the tax liability and who has the right to be paid by respondent. This is particularly true if a tribunal might wish to grant claimant and its parent company, unlike the Mobil tribunal did, to order respondent to pay the extra taxes that would be allegedly be owed consequent to a transfer of the amount of the awarded sum from the liable host State to the State of origin of the original investment. ${ }^{49}$

44 See Mobil v Canada (n 39), para 485.

45 Tobis (n 35), 19.

46 Mark Kantor, 'Chapter 4: Important Components of DCF Valuations', in Mark Kantor (ed) Valuation for Arbitration (Wolters Kluwer 2008) 131, 192-3.

47 This type of valuation is probably easier for States such as the Republic of Italy, where tax liability on damages awarded is calculated on the basis of the nature of the loss suffered based on the categories that the law establishes for different type of profits. See Article 6, para 2 of Presidential Decree no 917 of 22 December 1986 (so-called 'TUIR').

48 Tobis (n 35), 29.

49 For example, see Mobil v Canada (n 39) para 485:

The Majority sees little basis for incorporating the Claimants' request for a 38 per cent 'gross up' for tax reasons. The Claimants did not justify why compensation could not remain with the Canadian enterprises, nor why it had to be taxed in the United States, nor what the tax rate was, nor why this is a necessary part of any resulting compensation. Moreover, we are not aware of a requirement under international law to gross up compensation as a result of tax considerations. 
18.26 A complementing option to the ones above that the tribunal might choose to adopt is to ensure that claimant will be paid net of all taxes due to respondent, be liable for a precise given amount equal to what would have paid if there had not been any infringement or that the State will avoid imposing any tax at all (in these last two cases if it is respondent itself to offer such possibility through agreeing on taxing in a given way the amounts awarded). There have been cases where tribunals decided how the compensation will be provided (net instead of gross of local taxes) ${ }^{50}$ or to whom (if there are different claimants with the same mother company or claimants are a subsidiary and the mother, and one of them will not be subject to the taxing power of the respondent) ${ }^{51}$ with the view of impeding abuses of the respondent state (such as taxing the award with a 99 per cent tax rate on 100 per cent of the amount awarded). If a tribunal found to have the power to ensure the amount of net compensation owed versus the respondent and through the aid of applicable DTTs determined whether and how the amounts will be taxed in other jurisdictions, this would already constitute a step forward in ensuring full compensation with a greater certainty.

\section{INTERNATIONAL TAX DISPUTE SETTLEMENT}

18.27 Rights under IIAs will not always be affected by DDTs, but there might indeed be such circumstances. When IIAs do not have specific carve-outs, but are sufficiently broad as to cover violations of FET or any other investment right impacting tax matters, or any agreement between a foreign investor and the host State in matters of tax such as APAs, then there might be an overlap between different international dispute settlement mechanisms. One might also endeavour to ascertain whether failing to agree to start a Mutual Agreement Procedure (MAP, see para 18.34 below), failing to implement a MAP agreement or an arbitral decision under DTTs or the EU tax dispute settlement mechanism might constitute a violation of FET or other provisions in applicable IIAs. When this is the case, addressing international taxation concerns is not easy, especially in the case of complex multinational transactions, as above noted. This is why it is important to understand the context of international taxation disputes and what are the main standards of treatment of taxpayers internationally in this regard.

\section{The OECD approach to dispute settlement in international tax law}

18.28 Dispute settlement mechanisms within the international tax law arena are key elements which ensure the taxpayers' rights to fair and legitimate taxation. Tax litigation and connected issues typically arise from an audit. This is an assessment of whether the correct tax has been paid at the right time in accordance with the applicable domestic tax legislation. ${ }^{52}$ Due to the fact that international taxation matters typically have a complex factual background, there might be legitimate reasons for which a taxpayer might have a different understanding of its situation

50 Tenaris SA E Talta - Trading e Marketing Sociedade Unipessoal Lda v Bolivarian Republic of Venezuela, ICSID Case No ARB/12/23, Award (Spanish), 12 November 2016, para 790 available at: <https://www.italaw.com/sites/default/files/ case-documents/italaw8137_0.pdf> accessed 15 May 2020.

51 See, e.g., PSEG Global v Turkey (n 43), para 338.

52 Centre for Tax Policy and Administration, 'Forum on Tax Administration - Guidance Note: Guidance on Test Procedures for Tax Audit Assurance' (April 2010) 7, available at: <http://www.oecd.org/tax/administration/ 45045414.pdf> accessed 15 May 2020. 
with regards to its duties towards the local tax administration. ${ }^{53}$ At times, international standards will accept that there will be a range of correct results within which a taxpayer will be able to claim to have paid the amount due. This is the case of transfer pricing valuation. ${ }^{54}$

In accounting, transfer pricing has been defined as: 'the price one segment, of an organization (subunit, department, division and so on) charges for a product or service supplied to another segment of the same organization [...] [and] intercompany transfers between affiliates'. ${ }^{55}$

It may be noted that 'transfer price' is a neutral concept. ${ }^{56}$ In assessing the transfer price between affiliated entities, the most popular standard which has been used as the primary method of valuation is the arm's length principle. ${ }^{57}$ This principle is incorporated within the OECD framework (and art 9 of the 2017 Model Convention), and is defined in the following terms in relation to the powers of the tax administration to adjust multinational transfer price:

[Where] conditions are made or imposed between the two [associated] enterprises in their commercial or financial relations which differ from those which would be made between independent enterprises, then any profits which would, but for those conditions, have accrued to one of the enterprises, but, by reason of those conditions, have not so accrued, may be included in the profits of that enterprise and taxed accordingly. ${ }^{58}$

The arm's length principle has been frequently adopted even amongst non-OECD economies $^{59}$ for several reasons, one of which is the fact that multinational enterprises and independent entities are treated equally before the tax administrations. ${ }^{60}$ If the arm's length principle were correctly applied, ideally independent entities and multinational enterprises would suffer neither advantages nor disadvantages. ${ }^{61}$ To ascertain the arm's length value of a controlled transaction, the OECD has identified a series of methods which use comparable transactions or data of comparable companies in its TPG. The OECD TPG, although not specifically designed for matters other than transfer pricing ${ }^{62}$ have also been used by tax authorities to evaluate the revenue and worth generated by intangibles in patent box regimes. ${ }^{63}$

OECD Transfer Pricing Guidelines (n 27), chapter IV section A.

54 Ibid.

55 Elaboration of a definition given by Horngren and Foster in 1991 (Charles Horngren and George Foster, Cost Accounting: A Managerial Emphasis (Prentice Hall 1991, 7th edn) 855). See Shirin Rathore, International Accounting (PHI Learning 2009) 287.

56 Ad Hoc Group of Experts on International Cooperation in Tax Matters, 'Transfer Pricing: History, State of the Art, Perspectives' (2001) UN Doc ST/SG/AC.8/2001/CRP.6 2.

57 Ibid.

58 OECD Model Tax Convention (n 2), art 9; OECD Transfer Pricing Guidelines (n 27), chapter I, section B1, para 1.6.

59 OECD Transfer Pricing Guidelines (n 27), chapter I, section B1, para 1.6

60 Ibid., chapter I, section B1, para 1.8.

61 Ibid.

62 For example, note the observation at Ibid., chapter VI, section A.2, para 6.13.

63 For example, the Italian Patent Box regime. See for guidance Agenzia delle Entrate, 'Circolare N. 11/E. Chiarimenti in tema di Patent Box - Articolo 1, commi da 37 a 45, della legge 23 dicembre 2014, n.190 e successive modificazioni e Decreto del Ministro dello Sviluppo Economico di concerto con il Ministro dell'Economia e delle Finanze del 30 luglio 2015' (7 April 2016), available at: <https://www.agenziaentrate.gov.it/portale/documents/20143/239558/Circolare +11e+7+aprile+2016_AGE.AGEDC001.REGISTRO+BOZZE.0003638.06-04-2016-B_Circolare+11_sostituita.pdf/ 521608a1-41d9-c00b-faeb-0419fabd1557> accessed 15 May 2020. 
18.32 The application of such standard, however, may be difficult. This is why the OECD recommends the use of APAs which determine, before a transaction is made, 'an appropriate set of criteria (e.g., method, comparables and appropriate adjustments thereto, critical assumptions as to future events) for the determination of the transfer pricing for those transactions over a fixed period of time'. 64

18.33 APAs aim at providing a way to supplement traditional tax mechanisms in order to resolve in a more efficient manner transfer pricing issues, amongst other tax-related problematics. ${ }^{65}$ However, APAs with one jurisdiction only may not be sufficient. The absence of an agreement between more than one State can lead to tax controversy and double taxation. A bilateral APA process, where at least two jurisdictions discuss and approve an APA, is possible thanks to Article 25 of the OECD Model Convention, ${ }^{66}$ and should prevent such conflict. As noted with the FFT case mentioned above, having negotiated a multilateral APA in the EU may not be enough to prevent controversies due to state aid issues. The understanding of all the complexities and implications in play is a key aspect in securing the certainty which APAs strive to achieve.

18.34 This particular Article of the 2017 OECD Model provides for a mechanism called Mutual Agreement Procedure (MAP) through which tax authorities can agree on the tax base allocated to each jurisdiction, and for the taxpayer to request the start of arbitration if the tax authorities do not agree on the allocation of the tax base within two years, in a fashion similar to the arbitration procedure provided by the earlier Multilateral Instrument (or MLI) of 2016, although regulated in less detail. ${ }^{67}$ It must be noted that the arbitration proceeding can be initiated also for specific issues only. According to the OECD, this would distinguish international tax arbitration proceedings from other commercial or 'government-private party' arbitrations which instead aim at resolving 'the whole case'. ${ }^{68}$ Another possibility that this Article imposes on state parties is to endeavour to resolve through mutual agreement disputes concerning 'any difficulty or doubts arising as to the interpretation or application of the [c]onvention'. ${ }^{69}$ Both types of mutual agreement procedure may be carried out by communicating with each other directly, including through a joint commission consisting of themselves or their representatives'.70

18.35 The MAP procedure found at Article 25.1 of the Model Convention gives the possibility to taxpayers to request a MAP in parallel with domestic tax litigation. ${ }^{71}$ The procedure may start even when the taxpayer will be charged only in the future by a party to the Convention, as long as such a possibility arises out of a present action of one or both or the contracting States. ${ }^{72}$

64 OECD Transfer Pricing Guidelines (n 27), Chapter IV, section F.1, para 4.134.

65 Ibid.

66 Ibid., F.2.

67 OECD Model Tax Convention (n 2), art 25.5(b). See also OECD, Multilateral Instrument (MLI) and its Explanatory Statement (adopted on 24 November 2016 and entered into force on 1 July 2018), available at: <https://www.oecd.org/ tax/treaties/multilateral-convention-to-implement-tax-treaty-related-measures-to-prevent-beps.htm> accessed 15 May 2020.

68 Ibid., commentary to art 25.5 para 64.

69 Ibid., art 25.3.

70 Ibid., art 25.4.

71 Ibid., commentary to art 25 para 70.2 .

72 Ibid., commentary to art 25 para 13. 
This applies also to newly enacted laws regardless of whether they are of general or individual application, as long as their direct and necessary consequence is a violation of the Convention. ${ }^{73}$ To exercise such a right, the taxpayer must 'present his case' to the authority of either contracting State that is competent on the matter within three years 'from the first notification of the action' contested. ${ }^{74}$ However, the competent authorities may require the taxpayer to abide by any special procedure for filing that they deem appropriate, obliging the taxpayer to follow certain additional provided standards. ${ }^{75}$ For the competent authorities to accept a case, it should not be necessary for the taxpayer to have proven that there will be an infringement of its rights, but that the taxpayer has presented a reasonable case based on facts that can be established. ${ }^{76}$

Due to the right of the taxpayer to start the procedure at such an early stage where there has not yet been a damage or formal notification, the expiration date of three years' time within which tax authorities can be requested to settle the case might depend on the relevant circumstances. ${ }^{77}$ As mentioned above, if one or both authorities have found that there has been a violation of the Convention, they have received all sufficient information to make a decision on the matter, and if in two years' time they have not yet reached an agreement, the taxpayer may request in writing for arbitration to commence. ${ }^{78}$ This is possible only if no tribunal or court of one of the States has ruled on the matter. ${ }^{79}$

If arbitration has started, taxpayers may be required to sign a confidentiality agreement. In fact, the OECD suggests the implementation of the following provision in tax conventions, which is drafted on the basis of the MLI:

Prior to the beginning of arbitration proceedings, the competent authorities of the Contracting States shall ensure that each person that presented the case and their advisors agree in writing not to disclose to any other person any information received during the course of the arbitration proceedings from either competent authority or the arbitration panel. The mutual agreement procedure and the arbitration proceedings related to the case shall terminate if, at any time after a request for arbitration has been made and before the arbitration panel has delivered its decision to the competent authorities, a person that presented the case or one of that person's advisors materially breaches that agreement. ${ }^{80}$

Interestingly, while within the investment arbitration context there has been a push for transparency of the proceedings, it is the OECD itself that acknowledges that States may want all information provided to be kept private. ${ }^{81}$

The commentary on Article 25 also provides in an Annex a sample agreement that States may use to bilaterally bind themselves, in order to implement what may be considered the

73 Ibid., commentary to art 25 para 14.

74 Ibid., art 25.1.

75 Ibid., commentary to art 25 para 16.

76 Ibid., commentary to art 25 para 14.

77 Ibid., commentary to art 25 paras $21-24$.

78 Ibid., art 25.5.

79 Ibid.

80 Ibid., commentary to art 25 para 80.1 .

81 Ibid. 
'Arbitration Rules' that will be used in case of arbitration. In any event, the participation of the taxpayer is generally viewed as at times helpful, but always optional.

18.40 As will certainly be noted, international tax dispute settlement is a very peculiar mechanism which has developed in recent times to address concerns of transparency and taxpayer participation. The system has many similarities with some recent Brazilian IIAs. These treaties were signed with Mozambique and Angola, and do not provide for investor-state arbitration, but State-to-State arbitration only. ${ }^{82}$ At Article 4, both agreements constitute a Joint Committee, which aims to 'seek consensus and resolve amicably any questions or conflicts regarding the investments of the Parties'. ${ }^{83}$

18.41 Both agreements provide for the resort to the same mechanisms in case of dispute. It is possible for a party to the bilateral agreement to submit a question 'of interest of an investor [...] specifying the name of the interested investor and the challenges or difficulties faced'. ${ }^{44}$ Such a request will trigger the institution of a bilateral meeting, where, whenever possible, the representatives of the interested investor will participate at least in part. ${ }^{85}$ Nongovernmental entities may also participate if involved in the measure or situation that is the object of the consultation'. ${ }^{86}$ In case of dissatisfaction and inability to reach an agreement, parties may resort to state-to-state arbitration. ${ }^{87}$ As one can note, this type of system resembles a softer version of MAP procedures coupled to a form of arbitration in case of dispute.

\section{International tax dispute settlement in the European Union}

18.42 While the OECD has its own standard in terms of MAP and arbitration proceedings, it is probably the European Union that has implemented the most detailed binding and uniform protocol with the highest number of Member States parties to it so far, through the publication of a recent Directive of the Council (2017/1852), which allows for so-called 'final offer', 'last best offer' or 'baseball' arbitration, in additional to the more conventional method illustrated below. 88

18.43 This Directive was issued to implement interpretative provisions to the previous Convention on the Elimination of Double Taxation in Connection with the Adjustment of Profits of Associated Enterprises of 1990, and broaden the number of cases and persons falling within

82 Martin Dietrich Brauch, 'Side-by-side Comparison of the Brazil-Mozambique and Brazil-Angola Cooperation and Investment Facilitation Agreements' (International Institute for Sustainable Development, 2015) < http://www.iisd.org/ sites/default/files/publications/comparison-cooperation-investment-facilitation-agreements.pdf > accessed 15 May 2020.

83 Ibid., art 4.

84 Ibid., art 15.3 .

85 Ibid.

86 Ibid., art 15. The agreement with Angola at art 15.6 reads instead: '6. If it is not possible to resolve the dispute in the terms of paragraph 2 of this article by a recommendation of the Joint Committee, the Parties may resort to mechanisms of arbitration between States to resolve the abovementioned dispute.'

87 Ibid., art 15.3 .

88 Council Directive (EU) 2017/1852 of 10 October 2017 on tax dispute resolution mechanisms in the European Union [2017] OJ L265/1, preamble paras 2-6. The MLI too allows for such type of arbitration. This method of dispute resolution obliges the tribunal to choose between the two last offers provided by one party to the other, without explaining why, after parties have concluded their submissions. 
scope of the dispute resolution mechanism. ${ }^{89}$ The Directive was thought to help the reduction of time and resources necessary to solve cases of double taxation and to render them 'comprehensive, effective and sustainable'. ${ }^{90}$

A further aim of the measures implemented is to introduce an effective and efficient framework for the resolution of tax disputes which ensures legal certainty and a businessfriendly environment for investments in order to achieve fair and efficient tax systems in the Union' and to 'create a harmonised and transparent framework for solving disputes and thereby provide benefits to all taxpayers'. ${ }^{91}$ Interestingly, the Directive expressly indicates rules of transparency as the main means to create a fairer tax environment, jointly with anti-avoidance measures. ${ }^{92}$

In the Directive, arbitration is considered a useful tool only once there is an absence of agreement after a prolonged period of time, as a last resort mechanism. ${ }^{93}$ Similarly to the Investor-State Dispute Settlement (ISDS), the Directive envisages a system where the 'choice of the method for dispute resolution should be flexible, which could be either through ad hoc structures or through more permanent structures'. ${ }^{94}$

The Directive lays down some innovative methods to ensure that disputes will be solved. This is accomplished through the use of multiple layers and options for protection. The affected person ${ }^{95}$ has the opportunity and right to recourse to national courts to protect his interests in various circumstances. The Directive does not address exactly which are the 'Arbitration Rules' for each of the various mechanisms involved in the dispute resolution process, but is concerned more with providing for the protection of the affected person and the Member States involved. This is why it has only 24 articles.

Under the Directive, an affected person has the right to file a complaint. Following the complaint, the tax authorities will evaluate whether or not the complaint should be accepted. One of the Member States affected may also decide to unilaterally resolve the question submitted within six months of filing the complaint or the receipt of any necessary information requested. ${ }^{96}$ If the complaint is not accepted by all States, the affected person may, under certain conditions, ask for the institution of an Advisory Commission or may appeal at a national level under the law of the single Member State(s) rejecting the complaint. ${ }^{97}$ If any controversy on admissibility is solved in favour of the affected taxpayer, the matter will be subject to a MAP. If the MAP is successful, there will be implementation of the agreement, while if there is no agreement within the States affected, the matter can be resolved through arbitration. This can be made via an Advisory Commission or an Alternative Dispute

Ibid.: '[f]or this reason, it is necessary that there are mechanisms in the Union that ensure the effective resolution of disputes concerning the interpretation and application of such bilateral tax treaties and the Union Arbitration Convention, in particular disputes leading to double taxation'. See also preambles 6 and 7 of the same Directive.

90 Ibid., preambles 3-4.

91 Ibid., preamble 4.

92 Ibid.

93 Ibid.

94 Ibid.

95 Ibid., art 2.

96 Ibid., art 3.5.

97 Ibid., arts 5.3, 6.1. 
Resolution Commission, and with a flexible approach (including the use of 'last best offer' arbitration). States may implement the decisions taken by the Commission, or solve the matter differently through an agreement. In case of non-agreement, the decision of the Commission becomes binding. The details of the procedure are explained below.

18.48 As mentioned, the Directive grants to taxpayers the possibility of furthering a complaint due to the arising of double taxation on matters covered by its scope, and it is subject to certain formal requirements ${ }^{98}$ which are more extensive than the OECD proposed standards of the Annex to the Commentary on Article 25. Having received the necessary documentation, Tax Authorities have the opportunity to reject the application for a MAP if:

(a) the complaint lacks information required under Article 3(3) [...] including any information requested under Article 3(3)(f) that was not submitted within the deadline specified in Article 3(4));

(b) there is no question in dispute; or (c) the complaint was not submitted within the three-year period set out in Article 3(1). ${ }^{99}$

18.49 If one or more of the competent authorities does reject the application for the MAP, 100 the taxpayer should not despair: the Directive grants the possibility to appeal in front of an Advisory Commission within 50 days of notification of the decision. ${ }^{101}$ This recourse is possible only if the rejection was not unanimous. If so, the affected person can always appeal in front of competent organs identified by the national rules of each Member State involved.

18.50 If States have accepted or have been compelled to start a MAP, they have to do so within two years from the last notification of acceptance given to the affected person by one of the states concerned, save for a possible one-year extension. The affected taxpayer has the right to be notified both of the decision or of the reasons for the failure to reach a decision.

18.51 In cases where Member States cannot reach an agreement, they can be compelled by the taxpayer to settle the controversy through the establishment of the Advisory Commission. The panel of the Advisory Commission, nominated by the States involved in the failed MAP, may be constituted by a minimum of five members (in a bilateral MAP), with each State involved

98 See ibid., art 3.3(e):

(i) an explanation of why the affected person considers that there is a question in dispute; (ii) the details of any appeals and litigation initiated by the affected person regarding the relevant transactions and of any court decisions concerning the question in dispute; (iii) a commitment by the affected person to respond as completely and quickly as possible to all appropriate requests made by a competent authority and to provide any documentation at the request of the competent authorities; (iv) a copy of the final tax assessment decision in the form of a final tax assessment notice, tax audit report or other equivalent document leading to the question in dispute and a copy of any other documents issued by the tax authorities with regard to the question in dispute where relevant; (v) information on any complaint submitted by the affected person under another mutual agreement procedure or under another dispute resolution procedure as defined in Article 16(5) and an express commitment by the affected person that he will abide by the provisions of Article 16(5), if applicable;

see also, art 3.3(f): 'any specific additional information requested by the competent authorities that is considered necessary to undertake the substantive consideration of the particular case'.

99 Tax Dispute Resolution Directive (n 88), art 5.1.

100 Ibid., art 6.1.

101 Ibid. 
being able to appoint at least one representative and one independent person of standing. ${ }^{102}$ The independent person may be challenged only on a limited number of grounds. ${ }^{103}$

Even when the concerned States do not appoint members to the commission, the taxpayer has the right to compel the States to do so by bringing the matter to the national court of the State identified in the respective national law, or other body. ${ }^{104}$

Therefore, the mechanism devised guarantees in any case a solution of the problems of the taxpayer.

The EU regime also allows for the possibility of the creation of another type of entity to rule over the matter, the 'Alternative Dispute Resolution Commission' instead of an Advisory Commission. ${ }^{105}$ Its institution is based on the agreement of the tax authorities involved, and imposes in any event the observance of the impartiality of the independent person of standing of the panel in the Advisory Commission. ${ }^{106}$ The Alternative Dispute Resolution Commission might be of a permanent nature (a 'Standing Committee').

Once the request by the taxpayer to set up an Advisory Commission has been filed, the tax authorities have the duty to provide the taxpayer with the following documents within 120 days:

(a) the Rules of Functioning for the Advisory Commission or Alternative Dispute Resolution Commission;

(b) the date by which the opinion on the resolution of the question in dispute shall be adopted;

(c) references to any applicable legal provisions in national law of the Member States and to any applicable agreements or conventions. ${ }^{107}$

The regulation of the details of the management of the proceedings are dictated through the 'Rules of Functioning' of the Commission, which will have to contain several details on the procedure, with some limited exceptions for the Commissions established for an opinion with respect to a rejection of the complaint. ${ }^{108}$

(a) the description and the characteristics of the question in dispute; (b) the terms of reference on which the competent authorities of the Member States agree as regards the legal and factual questions to be resolved; (c) the form of the dispute resolution body, which shall be either an Advisory Commission or an Alternative Dispute Resolution Commission, as well as the type of process for any Alternative Dispute Resolution, if the process differs from the independent opinion process applied by an Advisory Commission; (d) the time frame for the dispute resolution procedure; (e) the composition of the Advisory Commission or Alternative Dispute Resolution Commission (including the number and names of the members, details of their competence and qualifications, and disclosing any conflicts of interest of the members); ( $f$ ) the rules governing the participation of the affected person(s) and third parties in the proceedings, exchanges of memoranda, information and evidence, the costs, the type of dispute 
18.57 It is mandatory for tax authorities and affected persons to cooperate with the panel upon request, save for limited exceptions. ${ }^{109}$ In particular, tax authorities may refuse to cooperate if:

(a) obtaining the information requires carrying out administrative measures that are against national law;

(b) the information cannot be obtained under the national law of the Member State concerned;

(c) the information concerns trade secrets, business secrets, industrial secrets, professional secrets or trade processes;

(d) the disclosure of the information is contrary to public policy. ${ }^{110}$

18.58 Persons affected by the panel's decision have the possibility, under limited circumstances, to appear in front of the panel to present their case, with the possibility of being represented. ${ }^{111}$

18.59 In any event, proceedings will terminate with an 'opinion' of the Commission within six months from the start at the latest through a majority vote, save for a possible three months' extension. ${ }^{112}$ Once the opinion has been rendered, the Member States will have the possibility within six months to agree on different terms for the solution of the case. ${ }^{113}$ Such a decision is final and binding, but does not constitute precedent, and will be implemented, save for the refusal of the affected person to renounce to any domestic remedy within 60 days from the notification of the decision. ${ }^{114}$

18.60 The decision rendered 'shall be implemented under the national law of the Member States concerned which as a result of the final decision shall amend their taxation, irrespective of any time limits prescribed by the national law' ${ }^{115}$ Therefore, it cleanses of any error the previous determinations of the local tax authorities.

18.61 In addition, the competent authorities, with the consent of the affected person, may decide to publish the decision in its entirety through procedures identified in implementing acts. ${ }^{116}$ In any case, it will be necessary to publish an abstract with 'a description of the issue and the subject matter, the date, the tax periods involved, the legal basis, the industry sector, and a short description of the final outcome'. ${ }^{117}$ The decision will also have to contain a description of the type of arbitration used, ${ }^{118}$ and the taxpayer will have the right to see redacted any information which 'concerns any trade, business, industrial or professional secret or trade process, or that is contrary to public policy'. ${ }^{119}$

resolution process to be used, and any other relevant procedural or organisational matters; ( $\mathrm{g}$ ) the logistical arrangements for the Advisory Commission's proceedings and delivery of its opinion.

109 Ibid., art 13.1.

110 Ibid.

111 Ibid., art 13.2.

112 Ibid., art 14.

113 Ibid., art 15 paras $1-2$.

114 Ibid., art 15.4.

115 Ibid.

116 Ibid., art 18.

117 Ibid., art 18.3.

118 Ibid.

119 Ibid. 
As one will note, more sophisticated provisions in relation to disclosure and transparency can be found in the Investment Arbitration field, in particular where the United Nations Commission on International Trade Law (UNCITRAL) Rules on Transparency in Treatybased Investor-State Arbitration are used within proceedings.

\section{SOFT LAW STANDARDS IN TAXATION AND THEIR POTENTIAL PRACTICAL USES IN INVESTMENT ARBITRATION}

As has been noted above, in international taxation there are harmonized and systematic procedures of treaty interpretation and dispute prevention and resolution. In addition, States often use the OECD Model ${ }^{120}$ when they enter into bilateral DTT's, and may end up with near to verbatim adoptions of the model. In addition to the Model, the OECD has issued interpretative guidelines. States and taxpayers can reasonably rely on these soft law instruments. ${ }^{121}$ This helps to limit in a systematic way the risk of unpredictable results in judgments of local courts in a system where there is no court having the ultimate word on the uniform interpretation of international tax provisions.

In investment arbitration, uncertainty on the strength of a claim has been found to lead to settlements only once arbitration proceedings have started, albeit at an early stage. ${ }^{122}$ This is why in international investment arbitration, it might be useful to look at international tax dispute settlement mechanisms to understand how to improve a system which has been deemed struggling to provide uniform interpretations to provisions. ${ }^{123}$

Notwithstanding its defects, international tax law may be useful for professionals operating in the international investment arena in limiting risks and uncertainty. Naturally, this will depend on the type of instrument (treaty, investment agreement or other) with which these will be negotiated and the actual circumstances of the matter at hand and the context of the application (with contracts or whether there are applicable umbrella clauses or not, for example). The use of instruments deriving from established tax practice might be considered favourably by the local government, since its own tax authority is used to implement these or similar practices already.

Several non-tax related matters in investment deals or arbitrations can be solved at least in part through the use of international tax standards. This might be done by States at international level or through international investment contracts by States and investors.

120 Commission, 'Guidelines for a Model for a European Taxpayers' Code' (2017), available at: <https:// un.org/esa/ffd/wpcontent/uploads/2018/05/MDT_2017.pdf> accessed 15 May 2020.

121 Brian J Arnold, 'An Introduction to Tax Treaties', 1 <https:// un.org/esa/ffd/wp-content/uploads/2015/10/TT_ Introduction_Eng.pdf> accessed 15 May 2020.

122 Roberto Echandi and Priyanka Kher, 'Can International Investor-State Disputes be Prevented? Empirical Evidence from Settlements in ICSID Arbitration' (2014) 29 ICSID Review 41, 56.

123 UNCITRAL, 'Report of Working Group III (Investor-State Dispute Settlement Reform) on the work of its thirty-sixth session (Vienna, 29 October-2 November 2018)' (A/CN9/964, 6 November 2018), paras 27-38, available at: <https://undocs.org/en/A/CN.9/964> accessed 15 May 2020. 
18.67 Naturally, it might be more useful for States themselves to reform international investment law on the basis of the opportunities offered by practices in the international tax regime. Although in the past it has been impossible for States to come to an agreement, and it seems impossible to find a unique type of treaty standard to fit all needs, it might still be possible to consider also the drafting of model clauses regarding the protection of substantive rights for an à la carte use, to compose a bilateral treaty according to the needs of the contracting parties.

18.68 Each type of provision and model would be accompanied with relevant comments, examples and instruction as to their interpretation and implementation, similarly as done by the OECD with DTTs. Comments might include reference to the relevant case law that has interpreted the relevant provisions. States might then decide to negotiate bilaterally or in a multilateral fashion changes to treaties already in existence, ensuring certainty in the application of the investment protection standards. This might be a solution which would have a certain appeal, since it would enable both investors and States alike to consider their positions with respect to a baseline which would be considered authoritative for all tribunals, unifying interpretation according to the type of clause chosen while ensuring that the choice in the wording used by each contracting State is respected. Similar instruments are already drafted by UNCITRAL with respect to the implementation of its model laws, where several drafting options are provided jointly with comments to the model provisions. ${ }^{124}$

18.69 In a way similar to how the OECD has drafted model guidelines with respect to the valuation of transfer pricing transactions, States may draft through international institutions one common document providing with step-by-step guidelines for experts in valuation of damages, in order to ensure the uniform application of valuation standards to the smallest possible detail. This would obviously not limit the role of experts and tribunals. However, it would enable parties to arising disputes to consider issues of valuation with more certainty. The project could build from the current World Bank Guidelines on the Treatment of Foreign Direct Investment to a much more detailed manual on valuation.

18.70 States may also consider implementing guidelines to direct tribunals on how comparable circumstances should be assessed in cases of application of, for example, the national treatment standard, just as in the TPG there is an indication as to how comparable transactions have to be identified.

18.71 In the alternative, investors may also contract some special provisions or regimes with host States. ${ }^{125}$ In international investment arbitration, it is possible for a tribunal to calculate damages on the basis of a contract provision. ${ }^{126}$ Although transfer pricing issues are still a matter of complex cases of valuation, transparent and predefined methods of calculation and choices of methodologies for valuation are of great aid to courts in tax matters, which may refer

124 See, e.g., the case of UNCITRAL, 'UNCITRAL Model Law on Secured Transactions - Guide to Enactment (2017) <https://www.uncitral.org/pdf/english/texts/security/MLST_Guide_to_enactment_E.pdf> accessed 30 May 2020; OECD Model Tax Convention (n 2), para 216.

125 See, for a complete discussion on responsibility for breaches of investment contracts and their legal framework, Jean Ho, State Responsibility for Breaches of Investment Contracts (CUP 2018).

126 Irmgard Marboe, 'Chapter 5: Methods of Valuations in International Practice' in Irmgard Marboe (ed) Calculation of Compensation and Damages in International Investment Law (OUP 2009) 213, 301-4. 
to predefined standards to make an accurate ruling. ${ }^{127}$ International investment practice has shown that including in contracts provisions for the calculation of damages may be helpful. ${ }^{128}$ In any case, tax law practice too shows that reference to specific best practices in choosing what is the most suitable methodology to apply in a given instance and how the method of valuation used should be used, greatly aid individuals called to judge on valuation matters, especially those lacking a specific quantitative background. ${ }^{129}$

In particular, even though the TPG have not been created for other regimes but for transfer pricing valuation only, parties may want to consider using or adapting the valuation methodologies therein for the estimation of the worth of intangible or tangible assets.

In addition, it would be useful to ensure through a provision that in cases where a tribunal or a judicial authority has the duty to evaluate the worth of the investment and award damages, it should apply Article 13 of the applicable DTT if relevant to the situation, if this has been drafted under the OECD Model, to ensure more certainty as to the tax treatment of the award. In any case, it should be good practice to ensure that such matter is addressed in an agreement. This provision would be useful also to avoid asking the tribunal for measures to avoid double taxation of the award. ${ }^{130}$

Another possible instrument useful in the prevention of litigation may be inspired by the possibility that taxpayers have to start a MAP even before any actual double taxation has taken place. To avoid potential costly litigation, the investor may contract with the State a clause according to which, if any measure is taken by the State or its organs which has violated or if applied might directly violate the investor's rights, it may ask the entity and the central government to avoid taking action, giving a preliminary statement of facts and rights. Such clause could also oblige the organ or central government to provide an explanation to its decision and as to why the investor's concerns are not justified. This might help the local authorities to understand the validity of the investor's claims and to assess before any liability is due whether the measure should or could be changed obtaining the same scope. This without violating the rights and limiting damages to the investor. It might also help the State entity to consider consequences not addressed when evaluating policy decisions. This type of approach may only work if there is a duty of the investor to signal the violation within a given timeframe to access directly investment arbitration, and if the exchange of opinions between the investor and the State entity is done in good faith. This type of clause would be particularly useful to avoid the need, whether present, for the investor to exhaust available local remedies and save time, while in the meantime giving the chance to the state entity to avoid liability. ${ }^{131}$

127 See as e.g., the use of the OECD guidelines imposed by the Court of Cassation of the Republic of Italy, 5th section, Judgment no 17953 of 19 October 2012.

128 Marboe (n 126), 301-4.

129 Demonstrated by the amount of references to the OECD Transfer Pricing Guidelines (n 27).

130 As happened in Occidental v Ecuador (n 39), para 851: 'During the quantum phase of this proceeding, the Claimants have sought confirmation on the part of the Respondent that it will not seek to collect taxes on any award that the Claimants may receive.'

131 Which is the ratio of a local remedies provision. See Martin Dietrich Brauch, 'Exhaustion of Local Remedies in International Investment Law' (International Institute for Sustainable Development, IISD Best Practices Series, 2017) 2, available at: <https://www.iisd.org/sites/default/files/publications/best-practices-exhaustion-local-remedieslaw-investment-en.pdf> accessed 15 May 2020. 
18.75 Finally, one could consider explicating in the arbitration agreement an actual statute of limitations or other clause indicating until when the claimant has the right to claim damages against respondent. Issues of statute of limitations are not addressed in the vast majority of IIAs. ${ }^{132}$ In international tax law, instead, taxpayers have a given limited timeframe in which they can start MAP procedures. Whether statues of limitations or similar provisions would be more useful to claimant or respondent depends on the actual amount of time accorded to start proceedings. A long period of time would favour claimant, a very short one respondent.

\section{E. CONCLUSION}

18.76 The interplay between international investment provisions and the local or international tax regime may have profound implications on the rights of an investor and their assessment. In the context of complex international transactions and structured investment, the impact of the applicable tax regime on investor rights should be carefully analysed by the tribunal called to solve an international investment dispute, and by the investor planning its operations.

18.77 This in particular when considering the valuation of damages and the consequences of the tax treatment of the amounts awarded on the investor. Since it is of primary importance to balance the rights of the respondent and of claimant, it is imperative to aim at understanding what are claimant's possibilities with respect to avoid, defer or limit tax liability on the amount awarded, and whether there are any ways to ensure that respondent will not overcompensate the claimant.

18.78 At the same time, it is necessary to ascertain how the single tax controversy should be settled. If it is possible for it to be done through a very early MAP process before the tax measure becomes definitive, this could avoid the potential costs of commencing an international Investment Arbitration claim, if both mechanisms of dispute resolution are accessible to the investor. The taxpayer/investor might also wish to consider the filing of both type of proceedings, if all legal requirements are met.

18.79 Most importantly, if there is the possibility, the investor should assess whether a cost/benefit analysis and the applicable legal framework enable a negotiation of some provisions within an investment contract inspired by the international tax regime to ensure more stability and certainty to the treatment of its investments.

132 See, for a deep analysis, Pedro J Martinez-Fraga and Joaquin Moreno Pampin, 'Reconceptualising the Statute of Limitations Doctrine in the International Law of Foreign Investment Protection: Reform beyond Historical Legacies' (2018) 50 NYU Journal of International Law and Politics 789. 